\title{
KEKAYAAN JENIS VEGETASI MANGROVE DI PANTAI MINANGA, KECAMATAN BINTAUNA, KABUPATEN BOLAANG MONGONDOW UTARA, SULAWESI UTARA
}

\author{
(Species Richness of Mangrove Vegetation on Minanga Beach, Bintauna District, Bolaang \\ Mongondow Utara Regency, North Sulawesi)
}

\author{
Kiki Marzuki Stion', Ratna Siahaan ${ }^{1 *}$, Eva L Baideng1
}

1. Program Studi Biologi, Fakultas Matematika dan Ilmu Pengetahuan Alam, Universitas Sam

Ratulangi - Manado 95115

*e-mail: ratnasiahaan@unsrat.ac.id

Mangrove is a typical vegetation type in the tropical coast near the mouth of the river and the beach which is protected from the strength of the waves. The ecological functions of mangroves are very important for various organisms. Human activities including land conversion can threaten the sustainability of mangroves which will result in disruption to the ecological functions of mangroves and decreasing of human welfare. This study aimed to analyze the species richness of mangrove vegetation on Minanga Beach, Bintauna District, North Mangondow Regency, North Sulawesi. The cruising method was carried out in the mangrove ecosystem starting from the land boundary (teresterial) to the estuary. A total of eight (8) points were distributed at the study sites which were divided into two (2) points on the back that bordered on terrestrial and each of three (3) points in the middle and front which bordered the estuary. A number of 18 species of mangroves were found, namely Acanthus ilicifolius, Acrostichum aureum, Aegiceras corniculatum, Avicennia lanata, Avicennia liliata, Avicennia marina, Bruguiera cylindrical, Bruguiera gymnorrhiza, Ceriops decandra, Clerodendrum inerme, Derris trifoliate, Heritiera littoralis, Hibiscus tiliaceus, Lumnitzera racemosa, Nypa fruticans, Rhizophora apiculata, Rhizophora mucronata, Sonneratia alba, and Xylocarpus moluccensis. The threats from human activities can cause declining of mangrove were land conversion and mangrove logging.

Keywords: mangrove, species richness, Minanga Beach

Mangrove merupakan suatu tipe vegetasi yang khas terdapat di daerah pantai tropis dan umumnya tumbuh subur di daerah pantai dekat muara sungai dan pantai yang terlindung dan terlindung dari kekuatan ombak. Fungsi mangrove secara ekologis yaitu sebagai tempat pemijahan (spawing), pengasuhan (nursey) dan tempat mencari makanan (feeding) bagi biota tertentu. Penelitian ini bertujuan untuk dapat menganalisis kekayaan jenis vegetasi mangrove di Pantai Minanga, Kecamatan Bintauna, Kabupaten Mangondow Utara, Sulawesi Utara. Metode jelajah dilakukan di ekosistem mangrove dimulai dari batas daratan (teresterial) hingga ke muara. Sebanyak dua petak di bagian belakang yang berbatasan dengan teresterial, tiga petak di bagian tengah dan tiga petak di bagian depan yang berbatasan dengan muara. Sebanyak 18 jenis mangrove ditemukan di Pantai Minanga, Kecamatan Bintauna. Ancaman yang dapat menyebabkan penurunan populasi mangrove yaitu konversi lahan dan penebangan kayu mangrove.

Kata kunci : Mangrove, kekayaan jenis, Pantai Minanga.

\section{PENDAHULUAN}

Indonesia merupakan negara kepulauan terbesar yang memiliki sekitar 17.500 pulau dengan panjang garis pantai sekitar $81.000 \mathrm{~km}$ (Bengen, 2001), sehingga memiliki potensi sumber daya pesisir laut yang besar. Salah satu komponen ekosistem pesisir laut yaitu hutan mangrove, merupakan sumber daya alam yang penting di lingkungan pesisir, dan memiliki tiga fungsi utama yaitu fungsi fisik, ekologis, dan ekonomis (Romimohtarto, 2001). 
Mangrove merupakan suatu tipe vegetasi yang khas terdapat di daerah pantai tropis dan umumnya tumbuh subur di daerah pantai dekat muara sungai dan pantai yang terlindung dari kekuatan ombak (Nursal et al., 2005). Fungsi mangrove secara ekologis yaitu sebagai tempat pemijahan (spawning), pengasuhan (nursey) dan tempat mencari makanan (feeding) bagi biota tertentu (Onrizal, 2008).

Keberadaan hutan mangrove amatlah penting dikarenakan mempunyai peran ganda disamping memiliki potensi ekologis dan juga memberikan manfaat ekonomi bagi kesejahteraan masyarakat disekitarnya. Keberadaan hutan mangrove sekarang ini cukup mengkhawatirkan karena ulah manusia untuk kepentingan konversi lahan sebagai tambak, pemukiman, perhotelan, ataupun tempat wisata. Hal ini diakibatkan dengan laju pertumbuhan pendudukan dan perkembangan pembangunan yang sangat pesat. Penebangan mangrove telah menurunkan populasi mangrove hingga lebih dari $50 \%$ dalam kurun waktu 30 tahun (Hari, 2009).

Data BPDAS Sulawesi Utara tahun 2011, luas total mangrove di Sulawesi Utara sekitar $12.977 \mathrm{Ha}$ pada tahun 2000 tetapi turun menjadi $11.546 \mathrm{Ha}$ pada tahun 2005 (Ramandalush et al., 2016).

Kawasan mangrove di Pantai Minanga, Kecamatan Bintauna merupakan salah satu kawasan yang terletak di Sulawesi Utara. Studi vegetasi mangrove belum pernah dilakukan di kawasan Pantai Minanga. Hal ini menyebabkan belum adanya data mengenai kekayaan jenis vegetasi mangrove di kawasan Pantai Minanga. Berdasarkan latar belakang tersebut, penelitian mengenai kekayaan jenis vegetasi mangrove di kawasan Pantai Minanga perlu dilakukan.

\section{METODE PENELITIAN}

\section{Lokasi dan Waktu Penelitian}

Lokasi penelitian terletak di Desa Minanga, Kecamatan Bintauna. Lokasi penelitian dibagi menjadi tiga (3) daerah teresterial/jalan hingga ke pantai yaitu bagian belakang mangrove berbatasan dengan jalan, tengah dan depan yang berbatasan dengan pantai. Aktivitas manusia pada lokasi penelitian tergolong tinggi .

Penelitian lapangan dilaksanakan pada Desember 2018 di Pantai Minanga, Desa Minanga, Kecamatan Bintauna, Kabupaten Bolaang Mongondow Utara, Sulawesi Utara Penelitian dilaksanakan di delapan (8) titik dari daratan hingga muara yaitu M1 hingga M8 (Gambar 1).

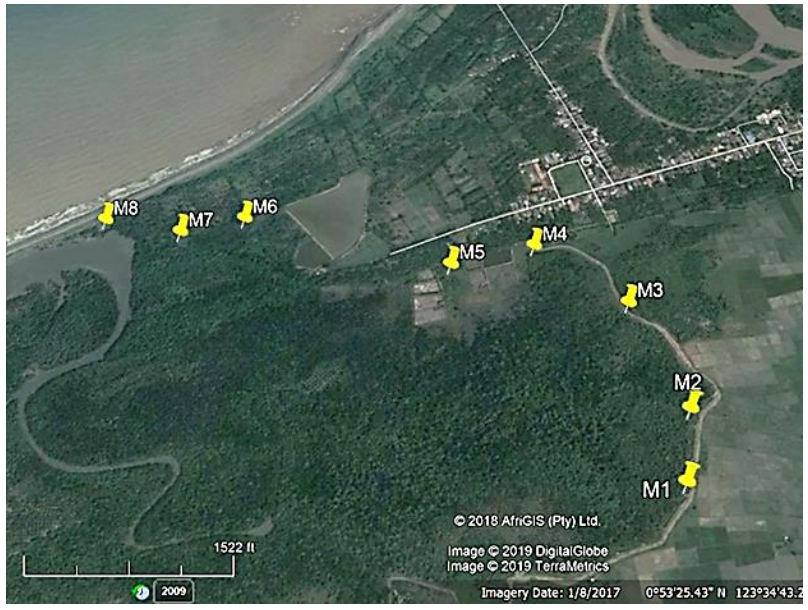

Gambar 1. Lokasi penelitian

(Sumber: Google Earth, 2019)

\section{Metode Pengambilan Sampel}

Penentuan Titik penelitian di lokasi penelitian Pantai Minanga, Desa Minanga, Kecamatan Bintauna dilakukan secara purposive sampling method yang didasarkan pada keterwakilan vegetasi mangrove dan aksebilitas ke lokasi. Metode jelajah dilakukan di ekosistem mangrove dimulai dari batas daratan (teresterial) hingga ke muara. Sebanyak tiga titik di bagian belakang yang berbatasan dengan teresterial, dua titik di bagian tengah dan tiga titik di bagian depan yang berbatasan dengan muara.

Setiap individu tumbuhan mangrove yang mewakili spesies yang berbeda yang ditemukan di lokasi penelitian, diamati dan diambil spesimennya untuk diidentifikasi 
lebih lanjut di laboratorium. Material herbarium yang terdiri atas daun, bunga/buah, ranting dari tiap jenis vegetasi diambil, diberi label gantung, dimasukkan dalam plastik lalu diberi alkohol. Seluruh material herbarium tersebut dibawa ke Laboratorium Ekologi, Jurusan Biologi, FMIPA Universitas Sam Ratulangi. Setelah dibiarkan semalam, material herbarium diatur dalam kertas koran dan diikat. Sampel dikeringkan di oven pada suhu $50^{\circ} \mathrm{C}$. Setelah kering, sampel diidentifikasi dengan menggunakan buku-buku identifikasi dari Noor et al., (1999) dan Kusuma et al., (2003).

\section{HASIL DAN PEMBAHASAN}

Mangrove yang ditemukan di lokasi penelitian berjumlah delapan belas (18) jenis dari dua belas (12) famili. Jenis mangrove yang paling banyak ditemukan Rhizophora mucronnata yang tersebar dari batas daratan hingga batas pantai.

Mangrove yang ditemukan di Pantai Minanga, Kecamatan Bintauna, Kabupaten Bolaang Mongondow Utara sejumlah 18 jenis lebih banyak dibandingkan dengan penelitian mangrove yang pernah dilakukan di Sulawesi Utara. Kekayaan jenis mangrove sebanyak 10 jenis di Pantai Kapeta dan Pantai Tanaki, Kecamatan Siau Barat Selatan (Kirauhe et al., 2016), enam (6) jenis di Pantai Tanamon, Kecamatan Sinon Sayang, Kabupaten Minahasa Selatan (Yuningsih et al., 2013), sembilan (9) jenis di hutan mangrove Likupang, Kabupaten Minahasa Utara (Sengkey et al., 2015), dan enam (6 jenis) di di Pulau Mantehage, Kecamatan Wori, Kabupaten Minahasa Utara (Lahabu et al., (2015).

Mangrove yang ditemukan di zona terbuka yang berbatasan langsung dengan laut (Titik 8) yaitu Avicennia lanata, Avicennia marina, dan Sonneratia alba. Mangrove yang ditemukan di zona payau yang dekat dengan sungai (Titik 1 dan Titik 2) yaitu Nypa fruticans. Berbagai jenis mangrove daratan ditemukan (Titik 1, Titik 2, Titik 3 dan Titik 8) yaitu Xylocarpus moluccensis, Hibiscus tiliaceus. Vegetasi mangrove lainnya tersebar di bagian tengah (Titik 1 hingga Titik 6) yaitu Acanthus ilicifolius, Acrostichum aureum, Aegiceras corniculatum Bruguiera gymnorrhiza, Bruguiera cylindrica, Clerodendrum inerme, Ceriops decandra, Derris trifoliata, Heritiera littoralis, Rhizophora apiculata, dan Rhizophora mucronata.

Jenis mangrove mayor/sejati yang ditemukan pada lokasi penelitian sebanyak sepuluh (10) jenis, yaitu Avicennia lanata, Avicennia marina, Bruguiera gymnorrhiza, Bruguiera cylindrica, Ceriops decandra, Lumnitzera racemose, Nypa fruticans, Rhizophora apiculata, Rhizophora mucronate, dan Sonneratia alba. Mangrove minor yang ditemukan sebanyak empat (4) jenis, yaitu Acrostichum aureum, Heritiera littoralis, Xylocarpus mulucensis, Aegiceras corniculatum. Mangrove asosiasi yang ditemukan sebanyak tiga (3) jenis, yaitu Acanthus ilicofolius, Clerodedrum inerme, Derris trifoliata, dan Hibiscus tiliaceus

\section{KESIMPULAN}

Kekayaan jenis vegetasi mangrove yang ditemukan di Pantai Minanga, Desa Minanga, Kecamatan Bintauna, Kabupaten Bolaang Mangondow Utara, Sulawesi Utara sejumlah 18 jenis dari 12 famili yaitu Nypa fruticans, Acrostichum aureum, Rhizophora apiculata, Acanthus ilicifolius, Heritiera littoralis, Derris trifoliata, Bruguiera gymnorrhiza, Xylocarpus moluccensis, Avicennia marina, Sonneratia alba, Ceriops decandra, Bruguiera cylindrica, Aegiceras corniculatum, Hibiscus tiliaceus, Avicennia lanata, Rhizophora mucronata, Clerodendrum inerme, Lumnitzera racemosa. Ancaman yang dapat menyebabkan penurunan populasi mangrove yaitu konversi lahan dan penebangan kayu mangrove. 


\section{DAFTAR PUSTAKA}

Bengen, D.G. 2001. Pengelolaan Sumberdaya Wilayah Pesisir secara Terpadu, Berkelanjutan dan Berbasis Masyarakat. Makalah pada Sosialisasi Pengelolaan Sumberdaya Berbasis Masyarakat. Bogor, 21-22 September 2001.

Hari, S. 2009. Biodiversitas Mangrove di Cagar Alam Pulau Sempu. Jurnal Sainstek. 8(1):59-63.

Kirauhe, I.V., R.Siahaan, J.J.Pelealu. 2015. Keanekaragaman Jenis Mangrove di Pantai Kapeta dan Pantai Tanaki, Kecamatan Siau Barat Selatan, Kabupaten Sitaro - Sulawesi Utara. 2015. Jurnal Bios Logos. 6 (1):1-6.

Kusuma, X., Onrizal dan Sudarmaji. 2003. Jenis-jenis Pohon Mangrove di Teluk Bintuni Papua. Fakultas Kehutanan IPB. Bogor.

Lahabu, Y., J.N. W. Schaduw, A.B. Windarto.2015. Kondisi Ekologi Mangrove di Pulau Mantehage Kecamatan Wori Kabupaten Minahasa Utara Provinsi Sulawesi Utara. Jurnal Pesisir dan Laut Tropis. 3(2): 41-52.

Noor, Y.R., M. Khazali, dan I.N.N. Suryadiputra. 1999. Panduan Pengenalan Mangrove di Indonesia. Bogor: Wetlands International Indonesia Programme.

Nursal, Y.Fauziah dan Ismiati, 2005. Struktur dan Komposisi Vegetasi Mangrove di Tanjung Seko di Kabupaten Bengkalis Riau, Jurnal Biogenesis 2(1):1-7.

Onrizal. 2008. Panduan Pengenalan dan Analisis Vegetasi Hutan Mangrove. Departemen Kehutanan, Fakultas Pertanian, Universitas Sumatera Utara.
Ramandalush, F., A.I.Santoso, S.Estuti A., A.A. Hutahean. 2016. Analisis Data Penginderaan Jauh untuk Mendeteksi Perubahan Luasan Mangrove Sebagai Sarana Pelindung Ekosistem Pantai (Studi Kasus di Kema, Kabupaten Minahasa Utara, Sulawesi Utara). Jurnal Chart Datum. 1(2):88-97.

Romimohtarto, K., S. Juwana. 2001. Biologi Laut: IImu Pengetahuan tentang Biota Laut.Puslitbang Oseanologi LIPI. Jakarta.

Sengkey, F.E., M. A. Langi, J. S. Tasirin, 2015. Struktur dan Komposisi Hutan Mangrove Likupang Kabupaten Minahasa Utara Provinsi Sulawesi Utara.Cocos. 6 (13):68-84.

Yuningsih, E., H.E.I Simbala, F.E.F Kandou, Saroyo. 2013. Keanekaragaman Vegetasi Mangrove di Pantai Tanamon Sulawesi Utara. Jurnal Bios Logos. 3 (2): 78-84. 